\title{
NATIVOS MAS NÃO CATIVOS: SOCIALIZAÇÃO COMUNISTA DESDE O BERÇO E PRODUÇÃO DE PAPEIS MILITANTES*
}

\author{
Catherine LeclercQ ${ }^{1}$
}

\begin{abstract}
RESUMO: Poderíamos pensar que a socialização política, quando inscrita desde a primeira infância em um espaço sociolocal onde a instituição comunista é onipresente, não poderia produzir outra coisa senão habitus militantes "em conformidade" e incondicionalmente leais aos princípios comunistas. No entanto, as entrevistas biográficas recolhidas em um antigo bastiáo operário do Partido Comunista Francês mostram que esse tipo de socialização, longe de se resumir a uma duplicaçáo de modelos parentais e a uma interiorização infalível das normas partidárias, permite processos de apropriaçáo oblíqua e de inovação. A reproduçáo do engajamento tende à produção evolutiva de papéis militantes de uma geração a outra.
\end{abstract}

Palavras-chave: Comunismo. Socialização. Habitus Militante. Reprodução. Adaptação.

\section{NATIVES BUT NOT CAPTIVES: COMMUNIST SOCIALIZATION FROM BIRTH AND THE PRODUTION OF MILITANT ROLES}

ABSTRACT: Some might take it for granted that political socialization, when it is part of a sociolocal space where the communist institution can be felt everywhere as soon as the earliest youth, could only produce but "regular" activist habitus and unconditional loyalties. Still, the biographical interviews conducted in a former workers' stronghold of the French Communist Party show that this kind of politicization, far from being restricted to a replication of parental models and an infallible internalization of partisan norms, do allow processes of oblique and innovative appropriation. The commitment's reproduction thus relies on - rather than stands against - the evolutionary construction of activist roles from one generation to another.

Keywords: Communism. Socialization. Activist habitus. Reproduction. Adaptation.

\footnotetext{
*Este campo de pesquisa corresponde a uma antiga zona de exploração de carvão, cujos poços foram fechados nos anos de1970-1980.

${ }^{1}$ Université de Poitiers - Poitiers, France. Groupe de Recherches Sociologiques sur les Sociétés Contemporaines (GRESCO). E-mail: catherine.leclercq@univ-poitiers.fr DOI: 10.1590/ES0101-73302016165996
} 


\section{NATIFS MAIS PAS CAPTIFS: SOCIALISATIONS COMMUNISTES « AU BERCEAU » ET FABRIQUE DES ROLES MILITANTS}

RESUME: Il pourrait sembler acquis que la socialisation politique, lorsqu'elle s'inscrit dès la prime enfance dans un espace socio-local où l'institution communiste est omniprésente, ne saurait produire que des habitus militants "conformes" et des loyautés inconditionnelles. Pourtant, les entretiens biographiques recueillis dans un ancien bastion ouvrier du Parti communiste français montrent que ce type de politisation, loin de se résumer à une duplication des modèles parentaux et à une intériorisation infaillible des normes partisanes, autorise des processus d'appropriation oblique et d'innovation. La reproduction de l'engagement s'adosse ainsi, plus qu'elle ne s'oppose, à la fabrique évolutive des rôles militants d'une génération à l'autre.

Mots-clés: Communisme. Socialisation. Habitus Militant. Reproduction. Adaptation.

\section{Introdução}

$\mathrm{P}$

ara mim é bem simples, eu nasci no partido." É o que diz um antigo militante do Partido Comunista Francês (PCF), nascido às vésperas da Segunda Guerra Mundial e engajado durante trinta anos nas atividades da Federação Comunista de Pas-de-Calais, região do norte industrial da França. Esta fórmula, "nascido no partido" (e suas muitas variaçôes: "banhado no comunismo", "militante de berço", "alimentado pelas lutas", "estar lá dentro desde o nascimento", etc.) foi ouvida várias vezes durante nossa pesquisa sobre as trajetórias de antigos militantes do PCF (LECLERCQ, 2008). Esta forma de apresentar as origens do engajamento comunista, especialmente recorrente e consistente no material biográfico, levou-nos a definir uma categoria, os nativos, que, em contraste com a dos convertidos, designa os entrevistados cujo ativismo deriva de uma continuação da socialização primária (BERGER, LUCKMANN, 2002), a ponto de ser apreendido, evidentemente, como extensão "natural" dos anos de infância e juventude. Essa categoria permite aprofundar as lógicas da herança política, questionando as condiçóes práticas da "filiação das afiliaçóes" (MOLINARI, 1996), mas também o grau de reprodução dos esquemas de interpretação e de ação que se constroem nessas "crianças vermelhas". De fato, se esse tipo de matriz sociobiográfica de engajamento alimenta uma relação naturalizada e, em alguns aspectos, em fusão com a instituição partidária, ela não é redutível a uma inscrição incondicional, ao contrário do que sugerem as noções de "programação" ou "doutrinação", que são, por vezes, usadas para qualificar — ou desqualificar — as formas precoces de politização. 


\section{"Nascidos no partido": uma relação naturalizada com o comunismo}

Como entender a formação, em alguns entrevistados, do sentimento de ter "nascido comunista"? Longe de comparar sua adesão partidária a um "segundo nascimento", eles reconstroem suas vidas como enraizada desde o início em uma matriz militante, destinados a realizarem-se nas posiçóes do PCF. Para se ter dimensão dessa espécie de amor fati (BORDIEU, 1980), é importante mostrar como agem os determinantes sociais e, mais precisamente, familiares, sobre os destinos individuais. Porque, se sabemos que os futuros militantes relacionam-se, em muitos casos, com a lógica da herança, ainda nos resta questionar os mecanismos socializadores trabalhados nessas trajetórias.

Para nortear essa pesquisa, mobilizaremos os instrumentos de uma história social oral do comunismo francês, a saber: entrevistas biográficas recolhidas na bacia mineradora da região francesa de Pas-de-Calais feitas com antigos militantes do PCF. Os entrevistados aqui citados nasceram entre os anos 1920 e 1930, em famílias comunistas: são herdeiros da "geração de fogo", que chegou ao partido depois do Congresso de Tours em reaçáo à guerra, e da "geração fundamental" registrada entre 1924 e 1934 (KRIEGEL, 1968). Todos são advindos de uma "classe operária", que foi estruturada durante os seus anos de juventude, em parte sob o efeito da implantação do PCF em grandes polos de trabalhadores (MISCHI, 2009). A este respeito, se eles são levados a declararem-se comunistas de nascimento, é porque incorporaram a definição do PCF como "partido da classe operária" - definição reivindicada com sucesso pelo partido, e realidade sociológica em grande parte do mundo operário até os anos 1960.

Se a relação entre pertencimento operário e pertencimento comunista reflete a eficácia (hoje inexistente) do trabalho partidário de apropriação simbólica da "classe operária" e da formação de uma equipe política operária fundada para representar a classe no campo político, ela não seria suficiente para explicar a propensão dos militantes a viverem como, literalmente, "gerados" pelo partido. As entrevistas biográficas permitem encontrar, mais precisamente, as condiçóes sociais de tal relação entre indivíduos e instituição partidária. Já que não será possível analisar aqui todos os mecanismos envolvidos nessa relação, insistiremos em um aspecto repetitivo nas histórias dos nativos, ou seja, a influência de um componente do seu etos de classe, o "familiarismo operário" (SCHWARTZ, 1990), em particular a sua internalização, na infância, das disposiçōes constitutivas do habitus militante de seus pais,não sob a forma de conhecimentos especializados e discursivos, mas de categorias éticas e práticas, isso em contextos históricos e configuraçôes locais marcadas por uma influência comunista variável, promovendo socializaçóes especialmente homogêneas. A ação socializadora da família é, assim, a de inserção no "meio partidário" (SAWICKI, 1997) alimentado por atividades do PCF, de suas "organizaçóes satélites" e de seus grupos defensores. Neste aspec- 
to, as histórias dos nativos contribuem para o conhecimento de um antigo estado da instituição comunista, que poderia criar em seus feudos operários verdadeiros ecossistemas locais, próprios a enquadrar as existências "do berço ao túmulo".

\section{Os pais modelos}

Os nativos internalizam muito cedo, seguindo lógicas éticas, práticas e afetivas, mais do que discursivas e ideológicas, seu pertencimento a uma "família política”, em todos os sentidos. Seguindo um padrão comum em áreas monoindustriais, onde o PCF foi muito influente, os entrevistados oriundos de comunidades mineiras de Pas-de-Calais fazem parte do parentesco militante que se assemelha, para alguns, a verdadeiras dinastias comunistas, fundadas junto com o próprio partido. Estas infâncias foram marcadas pela identificaçáo com as personalidades militantes da família, facilmente heroizadas e integradas à epopeia partidária.

Emile, mineiro aposentado, é um "típico" caso de comunista nativo. Ele começa sua história com estas palavras: "Eu nasci lá dentro. Meus pais sempre tiveram uma etiqueta vermelha”. Nascido em 1938, em uma família de mineiros do Norte da França, que logo se instalaram em Fouquières, perto de Lens. A partir daí, toda sua existência está ligada ao Partido Comunista, a ponto de o engajamento ser visto não como uma adesão escolhida, mas como uma condição original: "Meus pais não paravam de falar de política. Eu sempre conheci o PC, eu não conhecia mais nada de política”. Seu pai e seu avô são ex-combatentes da resistência, ambos militantes comunistas desde o início: "Eles venderam os primeiros jornais publicados pelo partido." Esses dois personagens, fiéis ao PCF até a morte, são centrais na construção de Emile e continuam a fazer parte de seu sistema de valores. Eles formam, com os veteranos de sua geração, uma elite militante pioneira, "os antigos", que são movidos por uma ética de engajamento total e desinteressado. O relato de Emile revela a nostalgia de uma época de ouro do comunismo, na qual os mais velhos "tinham na mão" o jogo partidário local e a felicidade militante era óbvia: "Os alemães ainda estavam em Fouquières enquanto estava aprendendo a Canção do Partido e a Internacional. [...] Quando se é jovem, não se sabe bem o que fazer. Eu estava feliz, estava aprendendo a cantar". A aquisição dessa cultura militante não tem nada de reflexiva: "feliz" e não tendo "conhecido mais nada", Emile opera em um comunismo de provas. "Na idade de 18 anos, comecei a levantar a bandeira". De seu compromisso com o partido, ele dá apenas esta interpretação, que continua a ser o fio condutor de sua história: "Eu segui a linha do meu avô e do meu pai". A linha como caminho traçado pela linhagem, mas também a linha no sentido partidário, ou seja, o modelo militante seguido pelos antigos. Tanto em batalhas políticas como na ética pessoal, Emile define sua conduta em referência a esta ascendência exemplar. Seu comunismo é aquele das figuras de autoridade de sua infância, e é com a desvalorização desse modelo que ele deixará de se identificar com o partido. 
A importância da transmissão familiar na relação de Emile com o PCF não é um caso especial. Os eixos de sua história são constantes nos discursos dos nativos: a aprendizagem precoce das atitudes e da moral militantes, a referência aos antigos, a adesão como "levantar a bandeira”. A própria família mostra-se como uma matriz de engajamento, especialmente nos locais de mineraçáo onde a magnitude reivindicada pelas linhagens militantes funciona como um suporte da honra social operária e uma vingança contra a falta de recursos legítimos. A dignidade operária atrelada ao engajamento comunista nunca é tão poderosa quanto no espaço familiar, local de persuasão permanente de uma ética proletária incorporada pelos pais e transformados em exempla. Seria errado negligenciar a eficácia socializadora dessas aprendizagens em regime de afetividade, tanto que elas se revelam decisivas na fabricação do vínculo partidário. Como prova, náo é raro que os entrevistados mencionem seus antepassados seguindo as lógicas da biografia exemplar, com formas de dessingularização próprias ao culto da personalidade operária militante ${ }^{1}$. O pai, em particular, cria um conjunto de projeções idealizadas que moldam o habitus militante de sua prole. Em filhos de líderes operários, a relação com a instituição comunista é construída de forma estreita em relação à figura paterna.

Irene, funcionária municipal aposentada, vive, no momento da pesquisa, em uma cidade mineradora no município de Sallaumines. Sua história é marcada pela exclusão do "eu" a favor de um "nós" coletivo que significa, por sua vez, sua irmandade, sua família, seu companheiro, o grupo operário e o partido. Filha de um oficial comunista de Pas-de-Calais, Irene mantém um discurso típico dos nativos, no qual o engajamento é indicado de acordo com o duplo registro da facilidade e da fatalidade. "Nós nos tornamos militantes um pouco pela força das coisas, com a família. Quando já se nasce em uma família de militantes, eu acho que é mais fácil, o percurso é feito naturalmente. Desde muito jovem, somos levados a encarar as coisas de frente e, em seguida, a militar, obviamente". Esses detalhes são os sintomas de uma socialização que tem um forte apelo ao ativismo comunista: "Quando somos jovens, não procuramos saber melhor, estamos impregnados dessas ideias".

Nascida em 1936 na cidade em que seu pai vencerá, algumas décadas mais tarde, um adversário socialista, Irene cresceu em um ambiente inteiramente comunista. Sua infância transcorreu na bacia mineradora, entre um pai oficial do partido e uma mãe orgulhosa de seu passado de resistente, que entrou no pósguerra para a União das Mulheres Francesas (UFF, filiada ao Partido Comunista). $\mathrm{Na}$ idade de quatorze anos, Irene segue com sua família para Lens, onde seu pai assumiria a direção do Sindicato dos Mineiros. De sua juventude, ele guarda sobretudo o exemplo de seus pais: seu pai, "um homem muito íntegro, muito honesto", sua mãe também, "uma militante dedicada”. "Meus pais eram um modelo de militantismo". Especialmente seu pai: autoritário, "stalinista", ocupado com o seu "sacerdócio", é a personificação do Partido Comunista. Antigo ferroviário 
de Houillères, ele se distinguiu pela sua exemplar trajetória militante: "ele subiu todos os escalóes". Notório líder sindical, logo se tornou membro permanente, ou seja, destacado para cumprir exclusivamente tarefas políticas no seio do PCF, integrou o Comitê Central e acumulou cargos eletivos, primeiro como conselheiro geral, depois como deputado e, finalmente, como prefeito. Por trás das qualidades paternas levantadas por Irene, reconhecemos o habitus dos líderes operários formados nos anos de 1930, munidos apenas do ensino primário básico, que se tornaram, dentro do PCF, autodidatas aplicados e militantes ascéticos. Irene, ciente do sentimento de ilegitimidade cultural de seu pai, espectadora de seu desejo pelo aperfeiçoamento ("Ele lia muito para tentar acompanhar um pouco, mas ele sofreu”), também teve uma breve escolaridade, interrompida no ensino médio para começar uma formaçáo de datilografia. Herdeira do engajamento dos pais, ela militará, por sua vez, mas "na base" - uma maneira de ficar "em seu lugar", abaixo desse pai inigualável que teve um percurso "sem erros".

Como Irene, muitos entrevistados atribuem a seus pais suas qualidades constitutivas da ética operária que "irriga o conjunto de práticas políticas dos militantes operários revolucionários que vão gradualmente ingressar no PC de 1920 a 1939" (PUDAL, 1989, p. 134). As virtudes paternas correspondem aos valores cardinais do proletariado, este "habitus operário adquirido" (PUDAL, 1989, p. 133) que consagra a abnegação, a honestidade, a assiduidade, a intransigência. Além disso, o personagem paterno encarna aqui um poder onipresente, que se estende do microcosmo doméstico à arena política nacional, passando por todos os cargos-chave no governo local: membro permanente do partido, líder sindical, deputado, prefeito e pai, ele é um desses "homens universais que normalmente acumulam altos cargos sindicais, municipais, partidários e, inclusive, familiares" (MOLINARI, 1996, p. 59). Entende-se que tal configuração produza formas duráveis de identificação partidária.

Se o pai está muitas vezes no centro das vocaçóes militantes, é porque ele geralmente detém, nas famílias operárias, o monopólio das atividades exteriores, enquanto a mãe tende a ser "a figura de ordem e guardiã da família" (SCHWARTZ, 1990, p. 180). Mas acontece, igualmente, de a mãe ser uma referência militante, como no caso de Gaston, mineiro aposentado, nascido em 1928, que inicia a entrevista dizendo: "É preciso voltar lá atrás. Eu nasci em uma família realmente engajada". Sua mãe, militante sindical e política, ela também comunista nativa, ocupa um lugar de destaque na história da sua vocação, a ponto de apagar o papel do pai, que "seguia o movimento". Inicialmente comprometida com o Sindicato de Peles em Paris, esta mulher enérgica mudou-se coma família para Lens, sua cidade natal, em 1943. Eleita no Conselho Municipal para a Liberação, ela logo assume um cargo no departamento de Lens do PCF e milita na UFF. A onipresença da política na vida familiar e, especialmente, na personalidade materna, marca profundamente o jovem Gaston: "Eu via o que ela fazia, eu lia os mesmos jornais que ela, eu via tudo o que acontecia”. É com o desejo de seguir 
os traços familiares que Gaston é contratado, com dezesseis anos, para o poço 9 das minas de Lens, antes de se estabelecer no poço 2 , onde um de seus primos era representante sindical. Ele simultaneamente entrou para a CGT, "era quase automático", e para a Juventude Comunista: "era um pouco a lei da família".

Os nativos mostram uma forte identificação com os membros do círculo familiar e, por extensão, à cultura comunista que eles carregam. Durante a infância, o comunismo corresponde menos à organização partidária que a um universo de atividades onde os pais, todo-poderosos, atuam como breviário. Eles são, por excelência, os significantes alheios que definem a realidade da criança e mediam a sua experimentaçáo do mundo, uma vez que têm pouca concorrência. "À medida que a criança não tem a menor escolha sobre os seus significantes alheios, sua identificação com eles é quase automática. Pela mesma razão, a interiorização de sua realidade particular é quase inevitável" (BERGER; LUCKMANN, 2002, p. 184).Assim como o mundo de uma criança é aquele que seus significantes alheios lhe mostram, o mundo desses filhos e filhas de militantes é comunista, e é o único possível.

\section{Uma "pedagogia implícita"}

As entrevistas mostram que a politização não é passada, principalmente, por mensagens explícitas, mas opera por meio de açóes repetidas, impulsionadas por princípios tácitos. Em relação à infância comunista, os entrevistados ratificam a ideia de uma "socialização executiva", realizada no âmbito das famílias operárias². A socialização política dos nativos recai menos sobre um conjunto de aprendizagem cognitiva que sobre uma "aprendizagem pelo corpo": o processo de aquisição

tende a realizar-se aquém da consciência e da expressão e, portanto, da distância reflexiva que supóe. $\mathrm{O}$ corpo [...] não representa o que ele interpreta, ele não memoriza o passado, ele age sobre o passado, táo anulado enquanto tal, ele o revive. O que é aprendido pelo corpo não é algo que se tem, como um saber que se pode ter diante de si, mas algo que se é (BOURDIEU, 1980, p. 123).

O conhecimento por meio do corpo é um componente sutil, porém onipresente, do material biográfico. Se os entrevistados salientam o papel das atitudes parentais em sua formaçáo política, raras são as lembranças de um programa educacional. A socialização das crianças, inclusive em sua dimensão política, é, antes de tudo, uma questão de rotina familiar, de copresença contínua, de mimetismo inconsciente em todas as trocas diárias. A inscrição na família "induz um conformismo do comportamento político, mais vivido que refletido" (MOLINARI, 1996, p. 57). Os condicionamentos familiares são ainda mais eficazes quando 
são retransmitidos pelos círculos de amizades, pelas organizaçóes juvenis e pelos encontros — paradas, manifestaçóes, reunióes — onde se pode observar e comunicar posturas, slogans e hexis militantes ${ }^{3}$. Marcel, nascido em 1926, mineiro que se tornou presidente da União Regional dos Sindicatos de Mineiros de Nord-Pas-de-Calais Regional, evoca as procissóes da Juventude Comunista, nas quais a pressão pelos números e códigos visuais contavam tanto quanto as palavras de ordem: "Tentávamos todos usar uma camisa branca, para melhor nos distinguir. $\mathrm{Na}$ frente iam os menores e atrás os maiores. Na época era assim, muito colorido”. A experiência da Juventude endossa um compromisso familiar forte, ritmado por cançóes comunistas e uma grande sociabilidade profissional, e marcada pelos "tumultos" na descida ao fundo da mina. A história de Marcel está repleta de referências às multidóes apertadas, às amizades viris, à celebração coletiva. "Reunir-se": este é o fio condutor desta juventude militante.

Nesses momentos em que o corpo é "tratado como um lembrete" (BOURDIEU, 1980) raramente foram feitas referências explícitas a ele, tamanha a cegueira para si mesmos, fundidos na prática repetida sem pensar. Mas, às vezes, as memórias sensoriais afloram com tantos indícios da dimensão corporal das construções identitárias comunistas. Trata-se de cantos, colagens, manifestaçóes, distribuiçóes de jornais na companhia de um pai ou um tio, folhetos escritos à mão, mais do que discussóes ou leituras. Assim, Denise, nascida em 1926 em uma família de ferroviários, esposa de Marcel, antiga militante da Federação de Pas-de-Calais, lembra, à sua maneira, da consistência corporal de sua formação política: "Nós vivemos 36, foi emocionante. Estávamos lá [Praça da Bastilha, em 14 de julho, em frente a Blum e Thorez] com meu pai, minha irmã estava sobre seus ombros e eu de mãos dadas coma mamãe [...]. E nas comemoraçóes do jornal L'Humanité, em Garches, lembro-me: 'Não empurre, tem crianças aqui' meu pai dizia, havia muitas pessoas lá. 'Não empurre!', isso ficou na minha cabeça. Foi assim que nos formamos, que entramos para a militância. Quando você é jovem, tudo é natural". "Tudo é natural": a expressão traduz bem a eficácia das aprendizagens primárias que se dão menos na ordem do discurso que naquela, onipotente, do corpo em ação. Poderíamos não prestar atenção a essas descriçóes fugazes de multidóes reunidas, empurróes, ombros paternos e mãos maternas, gestos trocados, expressóes faciais memorizadas, mesmo que não haja nenhuma garantia da veracidade do que foi "vivido" no passado. No entanto, o que importa aqui não é a precisão das memórias, mas sua textura visual, tátil, corporal e a impressão dos entrevistados de terem sido, literalmente, “jogados” à militância desde a infância.

A socialização dos nativos salienta, desse modo, a incorporação precoce de posturas militantes. Todos refletem uma formação política em atos, uma "mimesis prática" que assegura inconscientemente a reprodução do movimento militante. "E não cessaríamos de enumerar os valores que tomaram forma, pela transubstanciação que exerce a persuasão clandestina sobre uma pedagogia im- 
plícita, capaz de incutir uma cosmologia inteira, uma ética, uma metafísica, uma política" (BOURDIEU, 1980, p. 117). Os testemunhos de nativos mostram a dimensão estruturante dos aspectos subconscientes, extralinguísticos, da transmissâo familiar. Se existe um legado político, é menos sobre o modo de transmissão demonstrativa que sobre um conjunto de sensíveis inculcaçóes.

Entende-se que o sentimento de pertencimento original ao PCF está ancorado em experiências apropriadas a tornar o mundo comunista "o único mundo concebível". Os nativos são casos de estudo em matéria de socialização filtrada pelos significantes alheios: a realidade a eles apresentada com sua coloração comunista, sem nenhuma outra opção possível. "A socialização primária exerce [...] o que pode ser considerado como o mais importante papel que a sociedade tem para o indivíduo - fazer parecer necessário o que é, na verdade, apenas um pacote de contingências, e tornar significativo o acaso de seu nascimento" (BERGER ; LUCKMANN, 2002, p. 185). Essa fórmula, perto da "necessidade feita virtude" ou da "inclinação feita tendência" para Bourdieu, descreve bem o mecanismo pelo qual os indivíduos acabam dizendo terem "nascido no partido". Longe de resumir o engajamento dos militantes operários em uma ilusão, como fizeram alguns autores, nós o consideraremos, portanto, como uma illusio, esta capacidade de "ligar-se ao/envolver-se com o jogo" é melhor quando se "é nascido no jogo". $\mathrm{O}$ jogo, aqui é o jogo político que se desenrola em um local específico (área de mineração de Pas-de-Calais), em um período circunscrito (1925-1950) e em um estado do campo político no qual o PCF maciçamente assumiu a politização das classes populares.

Seria preciso descrever com mais precisão o ambiente local, onde a influência do PCF é exercida tanto nas atividades partidárias quanto nos grupos de jovens, associaçôes culturais, grupos de mulheres, associaçóes recreativas e desportivas, que participam, para os descendentes de linhagens militantes, de uma configuração socializadora totalizante. Entendemos, então, ainda melhor o sentimento de pertencimento originário e naturalizado no mundo comunista, resultado da história partidária materializada — registrada nas estruturas estabelecidas — e da história partidária incorporada - inscrita nos corpos militantes. No entanto, a coincidência estrutural entre a instituição comunista e seus nativos não funciona na forma de uma reprodução estrita dos habitus militantes ou de um conformismo imutável: estas formas precoces e totalizantes de politização não impedem nem as adaptações, nem as modificações nas maneiras de ser comunista.

\section{O "em casa" e o "quanto-a-si"}

Se os nativos incorporam as socializaçóes primárias, nas quais o mundo comunista é "o único mundo concebível", a "casa" (BERGER; LUCKMMAN, 2002), no qual, portanto, o envolvimento com o PCF acontece "naturalmente", 
estendendo as visões e divisóes de classe e os modos de ser da família, isso não leva a uma reprodução idêntica. Evitando os estereótipos sobre os condicionamentos primários, constata-se que, de fato, os papéis são "trabalhados" segundo as atividades e interaçóes militantes. Vários casos demonstram, assim, formas variadas de afastamento no que se refere às normas militantes dos antigos, às mudanças de regras saídas da "matriz stalinista" (PUDAL, 2009) e à insubordinação ocasional. Traremos, aqui, o caso de um antigo membro cuja história reflete uma espécie de dialética entre o engajamento e a distanciamento em relação às normas partidárias.

"Comecei muito jovem porque meu pai se engajou com o Partido Comunista em 1935”. É o que diz Denise, nascida em Aisne, em 1926. Seu pai e o partido parecem ser apenas um. É com esse ferroviário comunista que ela participa de grandes eventos políticos de sua infância: a luta contra a ascensão do fascismo (“34 me marcou”), a Frente Popular, a greve geral de 1938, a Ocupação, o Êxodo, a Resistência. Enquanto seu pai executava açóes clandestinas, Denise seguia seus passos. "Meu pai entrou para a Resistência. Nós o ajudávamos. Eu me lembro que transportávamos, junto com minha mãe, máquinas, um mimeógrafo, em outubro de 1940. Em 41 eu me filiei ao partido. [...] Eu me lembro de ter escrito à mão folhetos direcionados a mulheres. Com o meu pai, preparamos coquetéis Molotov, no prédio, em uma pequena sala de trabalho. Quando havia uma reunião para fazer com os camaradas, às vezes eu ia com os ferroviários. Meu pai me dizia: "você pode ir lá, e foi o que fiz". A formação militante de Denise dá-se no decorrer das ações resistentes, com os companheiros ferroviários e sob a tutela paterna. É na clandestinidade que Denise impregna-se da ética militante operária. "Eles nos diziam 'você sabe com o que está comprometida. Se você for presa, você será pressionada e torturada. Temos de encarar de frente'. Isso ficou muito marcado em mim. Meu pai era igual. Meu pai era a dignidade em pessoa. Ele certamente não denunciaria ninguém. Então, nós nos formamos assim. [...] Eu segui o exemplo. Muita dignidade".

O pai de Denise, responsável pelos Franco-atiradores militantes (FTP) em Pas-de-Calais, continua a ser o herói de sua juventude. "Eu tenho inclusive uma grande foto, lá na entrada, de um encontro de todos os FTP de Pas-de-Calais. Eles se reuniram, eles eram sete mil no parque Bollaert, com o meu pai e seus companheiros”. Quando, após a guerra, o homem foi afastado das posiçóes de liderança do PCF, sua filha adquire certo rancor contra o partido. Os aspectos subversivos de sua carreira militante provavelmente estáo ligados com o sentimento de ingratidão das autoridades partidárias em relação a seu pai.

\section{Linhas e limites}

Denise é uma figura representante da bacia mineradora. Moradora de Lens, não é apenas filha de um resistente comunista, mas esposa de líder sindical, 
ex-secretária particular de Auguste Lecoeur (prefeito de Lens em 1945, secretário de Estado para o Carvão em 1946), ex-membro do conselho da seção de Lens. Ela tem, no papel, o pedigree da militante modelo. No entanto, sua carreira é marcada por insubordinaçōes que ela atribui à sua "personalidade forte" e que the renderam várias disputas com os líderes do PCF. Neste sentido, a Denise revela uma lealdade atenuada, mistura de fidelidade e desrespeito. Constantemente "corrigida” pelos guardiôes da norma partidária, ela permaneceu comprometida com a "linha" do partido, quaisquer que fossem suas inflexôes. Sua história reflete a coexistência de uma forte incorporação da ética comunista consagrada pelo seu pai, adequada a torná-la uma militante totalmente dedicada à instituição, e disposta a reafirmar sua "independência de espírito" e liberdade de movimento, ela que se diz "no limite, um pouco individualista ". Suas palavras dão pistas dessa tendência a eclipses que lhe valerá uma carreira militante flutuante, alternando fases de investimento total e momentos de retirada.

A formaçáo de Denise no militantismo, como dissemos, é marcada pela figura paterna, modelo de engajamento e de ética operária, "a dignidade em pessoa”. Esse antigo chefe da federação comunista de Aisne encontra, na Liberação, o mesmo retrocesso partidário que muitos resistentes: "Todos aqueles que tinham alguma experiência na Resistência, certa notoriedade, eram 'expropriados' e substituídos por pessoas que não tinham participado da Resistência ou que não o tinham feito nas mesmas condiçôes, que não tinham tanta notoriedade assim. Havia um homem do Comitê Central que veio, que resolveu o problema e meu pai foi expulso assim. [...] Ele sempre teve o direito de ter seu cartão do partido, mas sobre a Resistência, pfff, não vamos mais falar disso!". O sentimento de abismo entre a bravura do pai e falta de reconhecimento partidária está presente na entrevista a tal ponto que não se pode excluir seu impacto sobre a relação relativamente distanciada de Denise com o partido. Como conceder ao aparelho comunista "crédito ilimitado" quando a história pessoal é marcada pelo rebaixamento de um modelo de dignidade militante?

Este episódio não impediu que Denise se engajasse ardentemente nas atividades partidárias e interrompesse sua escolaridade "pelo ouvriérisme": "Eu me encontrava deslocada entre os estudantes. Eu me encontrava deslocada, em contradição, já que eu queria manter o mesmo nível que os trabalhadores. Na minha cabeça, isso aconteceu assim. Então, eu não terminei o ensino médio. Fui levada pelo ouvriérisme. Denise dedicou-se, entáo, ao militantismo, acumulando pequenos trabalhos: empregada de um escritório, depois de uma farmácia, ela tornou-se secretária do Sindicato dos Mineiros de Lens, "um cargo de confiança”. Logo se tornaria membro permanente do PCF, ou seja, destacada com salário para se dedicar à atividades do partido como secretária de Auguste Lecoeur, líder da UFF e membro do secretariado da seção Lens. Enquanto isso, ela conheceu Marcel no Instituto Federal de Sallaumines em 1947. 
Desde aquela época, ela mostra uma relação bastante despreocupada em relação à regra do engajamento "vinte e quatro horas por dia": "Em um domingo, haveria uma venda em massa do Liberté [jornal comunista local]. Os militantes iriam para a rua, bateríamos de porta em porta, por exemplo, tínhamos cinquenta jornais. A seção tinha decido que tínhamos que vender tal quantidade, em tal cidade. Tá bom, tínhamos que passar a semana inteira na escola [do partido], depois vender... E com o meu temperamento um pouco individualista, no limite, 'aos domingos tem venda em massa', eu disse [no dialeto local] 'Pfff, eu não vou. Estou cansada, vou descansar um pouco'. Oh quem dera! No dia seguinte, desculpe, o que eu tive que aguentar! E foi anotado, feito um relatório e tudo! E esse camarada, o diretor da escola, me disse: 'O que você fez ontem?'. Eu disse 'Eu aproveitei para descansar' / 'E venda em massa do Liberté, você não fez!' / 'Bem, não, eu não fiz. / 'Mas isso é inaceitável! Você percebe, você está na escola e não participa nem mesmo da venda em massa do Liberte? Isso é inaceitável!'. Depois foi marcado no relatório, 'ausente na venda em massa do Libertee'”. Na sequência desse episódio, Denise evoca, em tom de autocrítica, sua propensão a cometer injustiças, infringir, quase contra si mesma, a disciplina partidária, o que lhe rendeu várias advertências. Seu testemunho exprime uma disposição individualista que a coloca em conflito com as regras do jogo. "Eles me disseram 'Você é um pouco egoísta'. Eu era engajada, mas eu tinha algumas reservas. Pode ser da minha natureza também, eu sinto que eu trago comigo. Isso me marcou. Eles me acusaram de não estar completamente envolvida. De ter uma individualidade muito acentuada”.

$\mathrm{O}$ "temperamento individualista" de Denise lhe rendeu várias reprimendas e, no momento do "caso Lecoeur", uma sanção da qual ela, paradoxalmente, mantém uma memória confusa. "Quando Maurice Thorez foi a Moscou, Lecoeur queria ser secretário nacional. Aconteceu alguma coisa em Pas-de-Calais, mas eu não lembro mais o que foi, qual era o caso ${ }^{4}$. Houve problemas com a gestão e eu interferi. Ele me convocou e eu disse: "Eu náo devo nada a você". Eles me colocaram para fora do Comitê Federal. [...] Havia certa desconfiança porque eu tinha tomado posiçôes que desagradaram, que iam de encontro à linha fixada. [...] Era sobre um fundo político, um comportamento que eu não concordava de jeito nenhum. Havia coisas que certamente me chocaram, críticas que fizeram a mim e eram injustificadas na minha opinião, e que eles consideravam justificadas porque era a linha. $\mathrm{Eu}$, a linha, há momentos... Mas não saberia mais o que dizer. A gente esquece, né”.

Denise expressa um jeito de ser comunista muito distante do espírito de partido geralmente atribuído aos trabalhadores militantes e, a fortiori, aos membros permanentes. No entanto, outros aspectos de seu discurso mostram sua capacidade de servir o partido e "alinhar-se" sobre as posiçóes oficiais. Por exemplo, ela não deixa de enfatizar a intensidade de sua crença no "paraíso soviético": "Quando me disseram pela primeira vez 'Você vai com a delegação para Moscou', eu comecei a chorar! Isso é para dizer como estávamos convencidos. Acreditávamos no que nos diziam. Era o paraíso, todo mundo era feliz, igual, humano. [Mais 
tarde, lembrando o nascimento de seu filho] Este filho nasceudia 05 de março de 1953, no dia da morte de Stalin. Eu disse ao menino, você ainda teve sorte de não ter se chamado Joseph Stalin!". Pró-soviética durante a Guerra Fria (a cadela da casa chamava-se Laika), Denise era a favor da União no momento da assinatura do Programa Comum e tornou-se antissocialista no final dos anos de 70: "Nós concordávamos com a União, realmente. Quando ela quebrou, como colocamos a culpa nos socialistas e naquele tempo houve uma corrente antissocialista, tolamente nós a seguimos. É verdade, nós seguimos".

O caso de Denise mostra que certa franqueza e uma propensão à reação contra o aparelho comunista não entram em conflito com um "seguidismo" de conjunto, especialmente porque o encaixe assegura um trabalho contínuo de normalização das condutas. Apesar das flutuaçóes de sua carreira militante e os problemas com os líderes, Denise sempre manteve seu compromisso e sua participação no PCF. Será preciso haver a divisão do meio partidário em dois campos opostos, na década de 1990, para que ela renuncie a seu cargo de responsável federal pelos veteranos e retire-se do jogo. Como outros militantes de sua geraçáo, ela se sentirá expulsa do PCF no momento em que sua federação terá autonomia em relação à liderança nacional, isto é, quando ela verá dividir-se e, finalmente, desaparecer, a "linha" do partido, esse conjunto ético e doutrinário que define "o credo, a crença, a obediência” (BOURDIEU, 1981).

\section{Uma lealdade obliqua}

Denise está longe de ser a única a expressar um comportamento militante em que a docilidade convive com manifestaçôes de insubordinaçâoo ou desenvoltura. O habitus comunista não é um sistema gerador de obediência absoluta, sinônimo de plena incorporação dos modelos existentes e de execução infalível das diretrizes institucionais. Se o "espírito de partido" significa uma disposição real e ativa para adotar as normas da organização, isso não exclui a insatisfação, sejam elas vividas ou não como tal. Essas diferenças, que têm mais que ser heroizadas do que ignoradas, referem-se a lógicas de modulação das restriçôes do papel militante e de gestáo dos impulsos individuais, bem analisadas por Goffman, em termos de "adaptaçōes" nas instituiçóes totais: se as adaptaçóes primárias transformam o indivíduo "colaborador", membro "programado"que "dá e recebe com o estado de espírito necessário, o que foi sistematicamente decidido", as adaptaçôes secundárias "representam para o indivíduo o meio de afastar-se do papel e personagem que a instituição naturalmente lhe atribui" (GOFFMAN, 1968, p. 245). Essas adaptaçóes secundárias são visíveis em diferentes fases da história do PCF, tanto entre os trabalhadores quanto nas fraçóes intelectuais do corpo militante - consideradas, erroneamente, como mais "reflexivas". O engajamento com o PCF, mesmo em períodos de maior "vigilância" partidária, deve ser entendido como uma dialética entre o eu eo jogo, entre o quanto-a-si e a entrega de si (PENNETIER; PUDAL, 2014). 
Vários entrevistados demonstram uma capacidade de "andar na linha", ajustando os produtos da sua socialização com os requisitos da disciplina partidária. Sua obediência náo se resume, portanto, a uma fides implicita, "delegação completa e total pela qual os mais pobres depositam, em massa, no partido de sua escolha, um tipo de crédito ilimitado" (BOURDIEU, 1981, p. 5). Os militantes das classes populares não são dedicados à desapropriação política pela delegação absoluta de sua expressão aos aparelhos. Ao contrário, é observado, no que diz respeito ao PCF, uma espécie de lealdade oblíqua ${ }^{5}$ integrando os escorregóes, os atos de desrespeito, as micro-subversóes. Esses fermentos de insubordinação refletem a relativa flexibilidade de papéis, ou seja, a possibilidade de administrar, por trás do rigor e da unanimidade aparentes, uma margem de ação individual. Embora as linhas iconoclastas sejam identificadas e punidas, não é incomum que as carreiras militantes revelem uma mistura de submissão às regras e acordos pontuais. Além disso, essa capacidade de ajustamento aparece, em muitos casos, como uma condição da permanência do engajamento. Lá onde os mais "fusionais" expóem-se, à primeira guinada político-estratégica ou à menor transformação morfológica, a uma "perda do mundo" (STRAUSS, 1992), os caçadores da lei institucional têm o poder de abraçar (dentro dos limites estabelecidos pelas suas disposiçóes sociobiográficas e sua posiçẫo partidária) as manifestações do "novo". O estudo dos engajamentos comunistas que são construídos em períodos de forte vigilância da ortodoxia e ortopraxia militantes, portanto, só podem ser conduzidos a partir de um conceito não evolucionista de habitus: se ele é um "sistema de disposiçóes duráveis e transponíveis" caracterizado por certa estabilidade e um poder de reprodução das estruturas sociais das quais ele é o produto, ele permite também uma margem de adaptação e inovação: "As disposições estão sujeitas a uma espécie de revisão permanente, mas que nunca é radical, porque opera a partir das premissas estabelecidas no estado anterior" (BOURDIEU, 1997, p. 231). As trajetórias de nativos do PCF são, de algum modo, manifestaçóes empíricas da reprodução como um processo dinâmico, em que os herdeiros descobrem variaçóes ligadas às mudanças de experiência e de geração dos sistemas de dispositivos. Pois, se as crianças incorporaram o gesto militante dos mais velhos, eles também o adaptaram ao longo da evoluçáo da instituição comunista, de seu capital coletivo e suas figuras sociais valorizadas. Os entrevistados da bacia mineradora podem até ter "nascido no partido", mas eles não se mantiveram ali sem adaptaçóes, dentro do limite dos ajustamentos possíveis entre suas disposiçóes incorporadas e as categorias instituídas.

Ao contrário do que poderia levar a uma leitura mecanicista da herança política, os indivíduos caracterizados por uma politização comunista "de berço" não são, portanto, sistematicamente induzidos a reproduzir as normas partidárias internalizadas durante a socialização primária, e podem manifestar formas de distanciamento do papel militante que é, paradoxalmente, uma condição para sua adaptação às mudanças institucionais e manutenção sustentável na organização. 
É tão somente nos contextos de grande revisão dos termos de compromisso, quando as reestruturaçóes de seu habitus militante tornam-se impossíveis e sua margem de açáo concreta reduz-se drasticamente, ou seja ,quando qualquer conivência entre o indivíduo e a instituição - mesmo com uma dose de "má fé" - torna-se impossível, que o engajamento é quebrado. Assim, o estudo aprofundado das trajetórias militantes revelam as condiçốes tanto de construção da ligação partidária quanto das lógicas da sua desintegração. Em última análise, o abandono por parte do PCF de seu papel de politização das classes populares poderia levar somente à desmobilizaçáo dos trabalhadores militantes nascidos em um estado anterior, e passado, do "partido da classe operária."

\section{Notas}

1. A noção de "singularidade anônima ", emprestada de Rémi Lenoir, traduz bem essa norma partidária característica da época (PUDAL, 1989, p. 210).

2. A noção de socialização executiva foi inspirada na de "política executiva" que designa, para Michel Verret, o estilo político da classe operária, herdado dos levantes revolucionários: "Política de ação, política em atos, pois a palavra em si: gritos, cançôes, arengas, hinos, é também um ato, mas o essencial acontece no corpo (VERRET, 1988, p. 225).

3. "A hexis corporal é a mitologia política realizada,incorporada,transformada em disposição permanente, maneira durável de manter-se, de falar, de andar e, nesse sentido, de sentir e de pen$\operatorname{sar}$ (BOURDIEU, 1980, p. 117).

4. Trata-se do suicídio, em 1954, René Camphin, militante da bacia mineradora próxima de Lecœur, no momento em que ele, acusado pelo Comitê Político do PCF de "oportunista", recusa explicar-se e pede demissão de todas suas funçôes partidárias.

5. Esse noção é construída por analogia à de "atenção obliqua" que designa, para Richard Hoggart a atitude das classes populares inglesas em relação às mensagens da mídia e da alta cultura, comparando-a a um "consumo indiferente", segundo o princípio do "pegar ou largar" (HOGGART, 1970, p. 296).

\section{Referências}

BERGER, P. ; LUCKMANN, T. La construction sociale de la réalité. Paris: Armand Colin, 2002.

BOURDIEU, P. La représentation politique. Eléments pour une théorie du champ politique. Actes de la Recherche en Sciences Sociales, v. 36, p. 3-24, 1981.

. Le sens pratique. Paris : Minuit, 1980.

. Méditations pascaliennes. Paris: Seuil, 1997. 
GOFFMAN, E. A. Etudes sur la condition sociale des malades mentaux. Paris: Minuit, 1968.

HOGGART, R. La culture du pauvre: étude sur le style de vie des classes populaires en Angleterre. Paris: Minuit, 1970.

KRIEGEL, A. Les communistes français. Paris: Seuil, 1968.

LECLERCQ, C. Histoires d'"ex». Une approche socio-biographique du désengagement des militants du Parti communiste français. Thèse (Doctorat en Science Politique) - Sciences Po Paris, Institut d'études politiques, Paris, France, 2008.

MISCHI, J. Servir la classe ouvrière: sociabilités militantes au PCF. Rennes: PUR, 2009.

MOLINARI, J-P. Les ouvriers communistes: sociologie de l'adhésion ouvrière au PCF. Paris: L'harmattan, 1996.

PENNETIER, C. ; PUDAL, B. Le sujet communiste: identités militantes et laboratoires du «moi ». Rennes: PUR, 2014.

PUDAL, B. Prendre parti: pour une sociologie historique du PCF. Paris: Presses de la FNSP, 1989.

. Un monde défait: les communistes français de 1956 à nos jours. Bellecombe-enBauges: Le Croquant, 2009.

SAWICKI, F. Les réseaux du Parti socialiste. Sociologie d'un milieu partisan. Paris: Belin, 1997.

SCHWARTZ, O. Le monde privé des ouvriers. Paris: PUF, 1990.

STRAUSS, A.L. Miroirs et masques. Une introduction à l'interactionnisme. Paris: Métailié, 1992.

VERRET, M. La culture ouvrière. Saint-Sébastien: ACL Édition, 1988.

Recebido em 30 de junho de 2016.

Aceito em 05 de setembro de 2016. 